\title{
Chemical composition of Cupressus lusitanica and Eucalyptus saligna leaf essential oils and bioactivity against major insect pests of stored food grains
}

\author{
Philip K. Bett ${ }^{\mathrm{a}, *}$, Arop L. Deng ${ }^{\mathrm{a}}$, Joshua O. Ogendo ${ }^{\mathrm{b}}$, Samuel T. Kariuki ${ }^{\mathrm{a}}$, \\ Maud Kamatenesi-Mugisha ${ }^{\mathrm{c}}$, Joel M. Mihale ${ }^{\mathrm{d}}$, Baldwyn Torto ${ }^{\mathrm{e}}$ \\ a Department of Biological Sciences, Egerton University, P.O. Box 536-20115, Egerton, Kenya \\ ${ }^{\mathrm{b}}$ Department of Crops, Horticulture and Soils, Egerton University, P.O. Box 536-20115, Egerton, Kenya \\ c Division of Medical Ethnobotany and Product Development, Department of Biological Sciences, Makerere University, P.O. Box 7062, Kampala, Uganda \\ d Department of Physical Sciences, Open University of Tanzania, P.O. Box 31608, Dar es Salaam, Tanzania \\ e Behavioural and Chemical Ecology Department, ICIPE, P.O. Box 30772-00100, Nairobi, Kenya
}

\section{A R T I C L E I N F O}

\section{Article history:}

Received 25 May 2015

Received in revised form

27 November 2015

Accepted 7 December 2015

Available online 22 December 2015

\section{Keywords:}

Cupressus lusitanica

Essential oil

Eucalyptus saligna

Insecticidal

Repellence

Toxicity

\begin{abstract}
A B S T R A C T
The leaf essential oils from Cupressus lusitanica, Miller and Eucalyptus saligna, Smith obtained by hydrodistillation were analyzed by GC/MS and also screened for their insecticidal and repellent effects against adult Tribolium castaneum, Acanthoscelides obtectus, Sitotroga cerealella and Sitophilus zeamais. The C. lusitanica oil contained mainly umbellulone $(18.38 \%)$ and $\alpha$-pinene $(9.97 \%)$ whereas the E. saligna oil was dominated by $\alpha$-pinene $(24.40 \%)$ and 1,8 -cineole $(24.26 \%)$. Bioassays showed that of the four insect species tested, $A$. obtectus and $S$. cerealella were the most susceptible to the oils, with $\mathrm{LC}_{50}$ values of $0.05-0.11 \%$ $\mathrm{v} / \mathrm{w}$ in contact toxicity and 4.07-7.02 $\mu \mathrm{l} / \mathrm{L}$ air in space fumigation. Except in T. castaneum with percentage repellence (PR) values of 65-92.5\%, the other test insects recorded PR values less than $30 \%$. The PR values decreased with exposure time in all insects except in $T$. castaneum. Our results show that $C$. lusitanica and E. saligna essential oils are promising insecticides and repellents to be used against insect pests of stored food grains.
\end{abstract}

(C) 2015 Elsevier B.V. All rights reserved.

\section{Introduction}

Food insecurity in smallholder agricultural is largely due to crop pests, plant diseases, and poor storage and post-harvest handling techniques (Deng et al., 2009; Ogendo et al., 2012). In Africa a combination of arthropod pests and fungi often constitute the single greatest source of postharvest loss $(\geq 50 \%)$ of stored products (Nukenine, 2010; Philips and Throne, 2010). Among insect pests, substantial post-harvest losses are caused mainly by Sitophilus spp., Sitotroga cerealella Olivier, Tribolium castaneum Herbst and Prostephanus truncatus Horn on cereals, Acanthoscelides obtectus Say and Callosobruchus spp. on grain legumes (Deng et al., 2009; Ayvaz et al., 2010). The maize weevil Sitophilus zeamais and Angoumois grain moth, $S$. cerealella are primary colonizers of maize both pre- and post-harvest exposing seed tissue to infestation by other insects, bacteria and fungi. Similarly, the red rust flour bee-

\footnotetext{
* Corresponding author.

E-mail address: pkkbett@yahoo.co.uk (P.K. Bett).
}

tle, $T$. castaneum, is a secondary pest of stored cereal grains or other dried foods causing significant losses because it consumes grains. At elevated temperature and moisture conditions, damage caused by this beetle facilitates an accelerated growth of molds, including toxigenic species (Philips and Throne, 2010; Ogendo et al., 2012). Similarly, the bean weevil A. obtectus is one of the most destructive pests of the kidney bean, Phaseolus vulgaris L. with losses estimated at 30\% in the Mediterranean region (Ayvaz et al., 2010).

In order to minimize cereal and legume losses, stored product insect pests are controlled using contact synthetic insecticides and fumigants including phosphine and methyl bromide, which is banned in some parts of the world. However, due to toxicity to humans and non-target organisms, insecticide resistance and resurgence of pests associated with synthetic insecticides, alternative remedies are being sought. Pesticides from natural sources, which are locally accessible and available, relatively inexpensive, biodegradable, less toxic to non-target organisms and less prone to resistance by insect species are considered potential candidates (Ogendo et al., 2012; Liang et al., 2013; Tucker et al., 2014). In this regard extracts from plants in the families Lamiacae, Ver- 
benaceae, Fabaceae, Leguminosae, Myrtaceae and Cupressaceae among others, have proven potent against a wide range of preand post-harvest insect pests (Koona, 2005; Karakoç et al., 2006; Polatoğlu et al., 2011; Athanassiou et al., 2013; Kariuki et al., 2013). Essential oils and their constituents are the most promising repellents (Mohan and Fields, 2002), contact toxicants (Rosman et al., 2007; Ogendo et al., 2008; Abay et al., 2012) and fumigants (Rajendran and Sriranjini, 2008; Campbell et al., 2010; Bett et al., 2013) against pests of stored products.

In previous studies, scientists have been prospecting Mexican cypress, Cupressus lusitanica (Cupressaceae: Pinales) and Sydney blue gum, Eucalyptus saligna (Myrtaceae: Myrtales) for protection of stored grains from insect infestation, pharmaceuticals and aromatherapy among other uses. The two aromatic plants are widely cultivated around the world as sources of fuelwood, electric poles, fencing posts, timber, ornamental purposes, shade and windbreaks. However, documented information indicate that $C$. lusitanica leaves are used to treat skin diseases caused by dermatophytes and to repel insects from stored grain and to alleviate coughs and cold symptoms (Kuiate et al., 2006). In addition, the essential oil is used in aromatherapy and massage to restore calmness, sooth anger, improve blood circulation, and treat coughs and bronchitis (Kamatenesi-Mugisha et al., 2013). In other studies, the essential oil has been reported to possess antibacterial activity against Bacillus cereus and antifungal activity against Aspergillus niger (Hassanzadeh et al., 2010). Similarly, E. saligna essential oil is also used as insect repellent and insecticidal agent (Brooker and Kleinig, 2006). In addition, the oil possesses a wide spectrum of biological activity including anti-microbial, fungicidal, insecticidal/insect repellent, herbicidal, acaricidal and nematicidal (Batish and Kohli, 2008). The insecticidal activity of eucalyptus oils has been associated with components such as 1,8-cineole, citronellal, citronellol, citronellyl acetate, $p$-cymene, eucamalol, limonene, linalool, $\alpha$-pinene, $\gamma$-terpinene, $\alpha$-terpineol, alloocimene, and aromadendrene (Batish and Kohli, 2008). However, bioactivity and concentration of essential oils varies with species, season, location, climate, soil type, and age of the leaves, fertility regime, and methods used for drying the plant material and oil extraction (Brooker and Kleinig, 2006).

Considering the above prospects of essential oils as control agents of stored product insect pests, the current study purposed to; (1) determine chemical composition of C. lusitanica and E. saligna leaf essential oils, (2) evaluate contact and fumigant toxicity and repellence of the essential oils against $T$. castaneum (Coleoptera: Tenebrionidae), A obtectus (Coleoptera: Bruchidae), S. cerealella (Lepidoptera: Gelechiidae) and S. zeamais (Coleoptera: Curculionidae).

\section{Materials and methods}

\subsection{Experimental conditions and rearing of test insects}

Bioassays were conducted at the Integrated Biotechnology Laboratory, Egerton University at a temperature of $28 \pm 2{ }^{\circ} \mathrm{C}$ and relative humidity of $65 \pm 5 \%$ and $24 \mathrm{~h}$ darkness. Clean dry maize, wheat and bean grains, were placed in aluminum foil and kept in the oven at $100^{\circ} \mathrm{C}$ for $24 \mathrm{~h}$ to eliminate any latent insect infestation. All the test insects were obtained from laboratory maintained cultures. $S$. cerealella, S. zeamais and A. obtectus were reared on whole maize, wheat and bean grains, respectively whereas adult $T$. castaneum were reared on broken wheat grains plus $5 \%$ brewer's yeast. In order to secure adults of the same age, all emerging adults were collected daily and transferred together in rearing jars for 2-5 days prior to use. Two to five days old emerging adult insects were used for bioassays.

\subsection{Collection and preparations of plant materials}

Fresh leaves of C. lusitanica and E. saligna were separately collected from branches of 7 year old trees from forestry demonstration plots in Busia, ( $\left.0^{\circ} 27^{\prime} 20.02^{\prime \prime} \mathrm{N}, 34^{\circ} 7^{\prime} 48.00^{\prime \prime} \mathrm{E}, 1216 \mathrm{MASL}\right)$, Kenya in August, 2012. On the spot identification of $C$. lusitanica and E. saligna species was carried out with the help of expertise, pictorial aids and literature materials (Kokwaro and Johns, 1998). Preserved specimens were forwarded to Prof. Samuel T. Kariuki, Plant Taxonomist, Department of Biological Sciences, Egerton University for authentic identification. The fresh leaf samples were air-dried under shade at ambient temperature $\left(18-28^{\circ} \mathrm{C}\right)$ for 14 days and further oven dried at $35^{\circ} \mathrm{C}$ for $48 \mathrm{~h}$. Dry leaf materials were then ground using an electric hammer mill (Wambua et al., 2011).

\subsection{Hydro-distillation of essential oils, analysis and identification of essential oil constituents}

The powdered material (500g) of C. lusitanica and E. saligna leaves were hydro-distilled using a modified Clevenger-type apparatus for $4 \mathrm{~h}$ and the floating oil which separated from water, was collected. The oil was then dried over anhydrous sodium sulphate and stored in the refrigerator at $4{ }^{\circ} \mathrm{C}$ until use. Each test essential oil $(1 \mu \mathrm{l})$ from the different plants was analyzed by gas chromatography (GC) coupled to mass spectrometry (MS) at the laboratories of the International Centre of Insect Ecology and Physiology (ICIPE), Nairobi on an HP-7890A (Agilent Technologies, Wilmington, USA) GC connected to an HP 5975C (Agilent, Wilmington, USA) mass spectrometer. The GC equipment was fitted with a non-polar HP5MS capillary column $30 \mathrm{~m} \times 0.25 \mathrm{~mm}$ internal diameter; $0.25 \mu \mathrm{m}$ film thickness with 5\%-phenyl methyl silicone as the stationary phase (J \& W Scientific, Folsom, USA). The carrier gas was Helium $\left(1.2 \mathrm{ml} \mathrm{min}^{-1}\right)$; oven temperature programmed at $35^{\circ} \mathrm{C}$ (for $5 \mathrm{~min}$ ) to $280^{\circ} \mathrm{C}$ at $10^{\circ} \mathrm{C} \mathrm{min}^{-1}$ and then held isothermal at $280^{\circ} \mathrm{C}$ for $10.5 \mathrm{~min}$; injection mode was splitless. Mass spectra were acquired at $70 \mathrm{eV}$ within a mass range of 38-550 Daltons (Da) with a scan time of 0.73 scans $\mathrm{s}^{-1}$ whereas the ion source was maintained at a temperature of $230^{\circ} \mathrm{C}$. Identification of the essential oil components was achieved on the basis of their retention indices (RI) (determined with reference to a homologous series of normal alkanes $C_{5}-C_{31}$ ) (Van Den Dool and Kratz, 1963).

The identity of essential oil constituents was further verified by comparison of their mass spectral fragmentation patterns with those reported in the mass spectra with library data (NIST05a and Adams MS HP, USA).

\subsection{Instant contact toxicity bioassay}

The instant toxicity of $C$. lusitanica and $E$. saligna leaf essential oils against adult S. zeamais, S. cerealella, A. obtectus and T. castaneum were conducted according to Asawalam et al. (2006) and Ogendo et al. (2008) with some modifications. Each test essential oil was applied to $10 \mathrm{~g}$ wheat and $20 \mathrm{~g}$ maize and bean grains in $100 \mathrm{ml}$ glass jars at five concentrations $(0.0,0.05,0.10,0.15$ and $0.20 \% \mathrm{v} / \mathrm{w})$. The negative control consisted of untreated grains whereas Actelic Super $(0.056 \% \mathrm{v} / \mathrm{w})$, and crude soya oil $(1.0 \% \mathrm{v} / \mathrm{w})$ purchased from Meya Ltd., Nakuru served as positive controls. The grains were then artificially infested each with 20 unsexed adult test insects. The numbers of dead insects were recorded at 24, 72, 120 and $168 \mathrm{~h}$ post-treatment to estimate adult insect mortality. The percentage adult mortality was computed according to Asawalam et al. (2006) 
and corrected for natural mortality using Abbott's formula (Abbott, 1925), respectively, in Eqs. (1) and (2)

Actual Mortality $(\%)=\frac{N_{\mathrm{D}}}{N_{\mathrm{T}}} \times 100$

Corrected Mortality $\left(P_{\mathrm{T}}\right)=\frac{\left(P_{\mathrm{O}}-P_{\mathrm{C}}\right)}{\left(100-P_{\mathrm{C}}\right)} \times 100$

where $N_{\mathrm{D}}$ and $N_{\mathrm{T}}$ represent number of dead and total number of test insects per jar; $P_{\mathrm{O}}$ represent observed and $P_{\mathrm{C}}$ control percent mortalities.

\subsection{Space fumigation bioassay}

In fumigant toxicity $C$. lusitanica and $E$. saligna leaf essential oils were tested against adult stages of S. cereallela, A. obtectus, S. zeamais and $T$. castaneum in space fumigation chambers (Shaaya et al., 1991; Ogendo et al., 2008). Twenty unsexed adults $\left(N_{\mathrm{T}}\right)$ of each test insect species were introduced into meshed metallic cages with $5 \mathrm{~g}$ of food (grain) and suspended from a hook in a 3.4 L flat-bottom glass flask space fumigation chamber. Each test essential oil was separately applied to provide dosages of $0,5,10,15$ and $20 \mu \mathrm{l} / \mathrm{L}$ air on small pieces of Whatman No. 1 filter paper and then suspended in the chamber slightly below the cage. A magnetic stirrer was used to ensure even distribution of fumigant in the chamber over a $24 \mathrm{~h}$ exposure period in the experimental room maintained at temperature of $28 \pm 2{ }^{\circ} \mathrm{C}$ and relative humidity of $65 \pm 5 \%$. The number of dead $\left(N_{\mathrm{D}}\right)$ insects was recorded $24,72,120$ and $168 \mathrm{~h}$ post-fumigation. The percentage adult mortality was computed according to Asawalam et al. (2006) and corrected for natural mortality using Abbott's formula (Abbott, 1925) as in Eqs. (1) and (2), respectively as above.

\subsection{Instant repellence bioassay}

The repellence (choice bioassay) test was conducted according to Ogendo et al. (2008) and Liang et al., 2013 with modifications. The base of a 14-cm diameter plastic Petri dish was lined with aluminum foil, divided into four equal parts and $2.0 \mathrm{~g}$ whole/broken wheat or $4.0 \mathrm{~g}$ bean or maize grain samples placed in each quarter equidistant to the center. Each essential oil, dissolved in $1 \mathrm{~mL}$ acetone, was evaluated at five rates $(0.00,0.05,0.10,0.15$ and $0.20 \%$ $\mathrm{v} / \mathrm{w}$ ) as an alternate untreated (control)-treated arrangement with four replicates per concentration. Control treatments consisted of choice bioassays with $0.5 \mu \mathrm{l} / \mathrm{g}$ of DEET ( $N, N$-diethyl- $m$-toluamide) as positive control and crude soya oil $(10.0 \mu \mathrm{l} / \mathrm{g})$ and no-choice all untreated and as negative controls. The treated grains were kept for $1 \mathrm{~h}$ to allow the acetone to evaporate. Twenty unsexed adult stages of S. cereallela, A. obtectus, S. zeamais and T. castaneum were then released at the center of the Petri-dish and the top secured using a plastic cover. The number of insects present in the control $\left(N_{\mathrm{C}}\right)$ and treated $\left(N_{\mathrm{T}}\right)$ grains were recorded $1,3,5$ and $24 \mathrm{~h}$ post-exposure. Percent repellence (PR) values were computed according to Ogendo et al. (2008).

Percentrepellence $(\mathrm{PR})=\frac{\left(N_{\mathrm{C}}-N_{\mathrm{T}}\right)}{\left(N_{\mathrm{C}}+N_{\mathrm{T}}\right)} \times 100$

\subsection{Statistical data analysis}

Insect mortality data were corrected for natural mortality using Abbott's formula (Abbott, 1925). Data on percentage mortality and repellence were corrected for heterogeneity of treatment variances using arcsine-transformation (Leatemia and Isman, 2004) before being subjected to one-way ANOVA using JMP 9 software (SAS Institute, 2010). Means were separated by the Tukey-Kramer honestly significant difference (HSD) test at the $5 \%(P<0.05)$ significance level (Sokal and Rohlf, 1995). The relationship between the oil concentration applied and percentage mortality was determined using Probit Regression Analysis of transformed (log base 10) data to estimate lethal concentration that kills $50 \%\left(\mathrm{LC}_{50}\right)$ of test insects (SPSS, 2010). Any two $\mathrm{LC}_{50}$ values in a column whose 95\% confidence limits did not overlap were regarded as significantly different (Finney, 1971; Talukder and Howse, 1994).

\section{Results}

\subsection{Chemical composition of $\mathrm{C}$. lustanica and $\mathrm{E}$. saligna leaf essential oils}

The leaf essential oils obtained by hydrodistillation of both plants yielded 0.35 and $0.38 \%(\mathrm{v} / \mathrm{w})$ of oil in C. lusitanica and E. saligna, respectively. Table 1 shows the retention time (min), retention index, chemical identity and relative percentage (\%) concentration of chemical constituents. The GC-MS analyzes enabled the identification of a total of 68 compounds in C. luistanica oil corresponding to $99.98 \%$ of the total oil whereas in E. saligna 49 compounds were also identified accounting for $99.94 \%$ of the total oil composition (Figs. 1 and 2). The major constituents identified in C. luistanica oil were umbellulone (18.38\%), $\alpha$-pinene $(9.97 \%)$, sabinene $(8.16 \%)$ and limonene (7.91\%). However, E. saligna oil was dominated by 1,8 -cineole (24.26\%), o-cymene (9.92\%) and $\alpha$ terpineol (8.81\%). Comparing the chemical groups of the two oils, $C$ lusitanica oil was dominated by oxygenated monoterpenes whereas that of E. saligna oil was mainly monoterpene hydrocarbons.

\subsection{Instant contact toxicity}

Instant toxicity bioassay showed that $C$. lusitanica and E. saligna leaf essential oils were toxic to adult T. castaneum, A. obtectus, $S$. cerealella and $S$. zeamais. The concentration of essential oil applied and time post-treatment significantly influenced the percentage adult mortality of all the test insects (ANOVA: $F_{(3,96)}=6.9-293$; $\left.{ }^{* * *} P<0.001,\right)$. At $2.0 \% \mathrm{v} / \mathrm{w}, \mathrm{C}$. lusitanica oil caused $84.2 \%$, and $86.0 \%$ mortality of $S$. cerealella and $A$. obtectus, respectively $24 \mathrm{~h}$ posttreatment (Fig. 3a). T. castaneum and S. zeamais was more tolerant with mortalities of 18.2 and $59.2 \%$ respectively $24 \mathrm{~h}$ post-treatment (Fig. 3a). Similarly, E saligna essential oil at $2.0 \%$ v/w, achieved $86.9 \%$ and $87.3 \%$ mortality in A. obtectus and S. cerealella, respectively, $24 \mathrm{~h}$ post-treatment (Fig. 3b). On the other hand, at the same concentration, the mortality in S. zeamais and T. castaneum were rather low, $10.0 \%$ and $11.8 \%$ respectively $24 \mathrm{~h}$ after treatment.

However, at longer exposure period moderate mortalities of $77.6 \%$ were observed with $C$. lusitanica oil against $T$. castaneum and $58 \%$ against $S$. zeamais $168 \mathrm{~h}$ post-treatment (Fig. 4a). Similarly, moderate mortalities of $56.3 \%$ were observed with $E$. salgna oil against $S$. zeamais and still low mortality of $19.7 \%$ in $T$. castaneum $168 \mathrm{~h}$ post-treatment (Fig. $4 \mathrm{~b}$ ).

C. lusitanica oil was highly toxic with $\mathrm{LC}_{50}$ values of 0.05 and $0.11 \% \mathrm{v} / \mathrm{w} 24 \mathrm{~h}$ after contact for $S$. cerealella and $A$. obtectus, respectively. On the hand oil at the same concentration it was less toxic to T. castaneum and S. zeamais with $\mathrm{LC}_{50}$ of 0.18 and $0.21 \% \mathrm{v} / \mathrm{w}$ respectively $24 \mathrm{~h}$ post-treatment. E. saligna oil had similarly high toxicity levels with $\mathrm{LC}_{50}$ values of 0.02 and $0.08 \% \mathrm{v} / \mathrm{w}$ for $S$. cerealella and A. obtectus respectively $24 \mathrm{~h}$ post-treatment (Table 2 ). T. castaneum and $S$. zeamais, were more tolerant to E. saligna oil at the same concentration with $\mathrm{LC}_{50}$ values of 0.19 and $17 \% \mathrm{v} / \mathrm{w}$ respectively $24 \mathrm{~h}$ post-treatments.

However, toxicity levels increased in C. lusitanica against $T$. castaneum and $S$. zeamais with $\mathrm{LC}_{50}$ of 0.11 and $0.13 \% \mathrm{v} / \mathrm{w}$ respectively $168 \mathrm{~h}$ post-treatment (Table 2). E . saligna oil also became more 
Table 1

Retention time (min), retention index and percent concentration (\%) of chemical constituents of Eucalyptus saligna and C. lusitanica leaf essential oils.

\begin{tabular}{|c|c|c|c|c|c|}
\hline $\mathrm{No}^{\mathrm{a}}$ & Rt (min) & Compound name & $\mathrm{RI}^{\mathrm{b}}$ & $\%$ E. saligna & $\%$ C. lusitanica \\
\hline 1 & 6.87 & 2,4-Dimethyl-3-pentanone & 804 & 0.09 & - \\
\hline 2 & 8.35 & Isovaleric acid & 861 & 0.24 & - \\
\hline 3 & 8.53 & 2-Methylbutanoic acid & 868 & 0.05 & - \\
\hline 4 & 8.63 & (Z)-3-Hexenol & 873 & 0.02 & - \\
\hline 5 & 8.82 & (E)-2-Hexen-1-ol & 880 & 0.02 & - \\
\hline 6 & 9.24 & 1,2-Dimethyl-1,4-cyclohexadiene & 896 & 0.02 & - \\
\hline 7 & 9.76 & 2-Methylpropyl-2-methylpropanoate & 918 & - & 0.12 \\
\hline 8 & 9.85 & Tricyclene & 922 & - & 0.06 \\
\hline 9 & 9.99 & $\alpha$-Phellandrene & 928 & 0.03 & 0.99 \\
\hline 10 & 10.12 & $\alpha$-Pinene & 935 & 24.40 & 9.97 \\
\hline 11 & 10.43 & $\alpha$-Fenchene & 948 & 1.58 & 0.51 \\
\hline 12 & 10.55 & Thuja-2,4(10)-diene & 954 & 0.11 & 0.06 \\
\hline 13 & 10.72 & Benzaldehyde & 962 & 0.05 & 0.01 \\
\hline 14 & 10.90 & 3-Methylbutyl propanoate & 969 & 0.12 & - \\
\hline 15 & 10.95 & Sabinene & 972 & 0.31 & 8.16 \\
\hline 16 & 11.29 & Myrcene & 987 & - & 2.29 \\
\hline 17 & 11.34 & (E)-Dehydroxylinalool oxide & 989 & 0.14 & - \\
\hline 18 & 11.58 & $\beta$-Phellandrene & 1000 & 0.16 & 0.48 \\
\hline 19 & 11.66 & $\delta$-3-Carene & 1005 & - & 6.93 \\
\hline 20 & 11.72 & Isoamyl isobutyrate & 1009 & 0.14 & - \\
\hline 21 & 11.80 & $\delta$-2-Carene & 1013 & - & 0.53 \\
\hline 22 & 11.95 & o-Cymene & 1023 & 9.92 & 5.81 \\
\hline 23 & 12.02 & Limonene & 1027 & - & 7.91 \\
\hline 24 & 12.10 & 1,8-Cineole & 1031 & 24.26 & - \\
\hline 25 & 12.17 & $(Z)$ - $\beta$-Ocimene & 1036 & 0.16 & 0.23 \\
\hline 26 & 12.31 & Phenylactealdehyde & 1045 & 0.12 & - \\
\hline 27 & 12.55 & $\gamma$-Terpinene & 1059 & 0.31 & 0.24 \\
\hline 28 & 12.71 & (E)-Sabinene hydrate(IPP vs OH) & 1069 & - & 0.47 \\
\hline 29 & 13.01 & p-Cymenene & 1092 & - & 1.33 \\
\hline 30 & 13.25 & Linalool & 1101 & - & 3.91 \\
\hline 31 & 13.32 & Isopentyl isovalerate & 1106 & 0.33 & - \\
\hline 32 & 13.48 & $p$-1,3,8-Menthatriene & 1115 & - & 0.16 \\
\hline 33 & 13.52 & endo-Fenchol & 1117 & 2.35 & - \\
\hline 34 & 13.56 & $\alpha$-Thujone & 1120 & - & 0.23 \\
\hline 35 & 13.64 & $p$-(Z)-Menth-2-en-1-ol & 1124 & - & 0.61 \\
\hline 36 & 13.72 & $\alpha$-Campholenal & 1129 & 1.81 & - \\
\hline 37 & 13.96 & [1S-( $1 \alpha, 3 \alpha, 5 \alpha)]-6,6$-dimethyl-2-methylenebicyclo[3.1.1]heptan-3-ol & 1143 & 7.13 & - \\
\hline 38 & 14.03 & Camphor & 1147 & - & 0.62 \\
\hline 39 & 14.11 & Camphene hydrate & 1152 & 0.53 & - \\
\hline 40 & 14.24 & Sabina ketone & 1159 & - & 0.22 \\
\hline 41 & 14.33 & Pinocarvone & 1165 & 3.02 & - \\
\hline 42 & 14.39 & Borneol & 1168 & 4.57 & - \\
\hline 43 & 14.51 & Umbellulone & 1175 & - & 18.38 \\
\hline 44 & 14.54 & Terpinen-4-ol & 1177 & 1.52 & 6.12 \\
\hline 45 & 14.66 & {$[\alpha, \alpha], 4$-Trimethyl-benzenemethanol } & 1184 & - & 1.25 \\
\hline 46 & 14.75 & $\alpha$-Terpineol & 1189 & 8.81 & 1.98 \\
\hline 47 & 14.86 & $\gamma$-Terpinen-7-al & 1207 & - & 0.19 \\
\hline 48 & 15.06 & Verbenone & 1208 & 0.53 & - \\
\hline 49 & 15.24 & Eucarvone & 1220 & - & 0.37 \\
\hline 50 & 15.33 & Terpinolene & 1227 & 1.43 & - \\
\hline 51 & 15.51 & Cumin aldehyde & 1238 & & 0.31 \\
\hline 52 & 15.71 & Piperitone & 1252 & 0.28 & 1.19 \\
\hline 53 & 16.19 & Thymol & 1284 & 0.27 & 0.76 \\
\hline 54 & 16.30 & Benzyl isobutanoate & 1291 & 0.08 & - \\
\hline 55 & 16.33 & Terpinolene & 1293 & - & 0.66 \\
\hline 56 & 17.02 & $\alpha$-Terpinene & 1342 & - & 2.60 \\
\hline 57 & 17.10 & 2,2,5,5-Tetramethyl-3-cyclopenten-1-one & 1348 & 0.15 & - \\
\hline 58 & 17.44 & $\alpha$-Copaene & 1373 & 0.11 & - \\
\hline 59 & 17.62 & Phenylethyl butyrate & 1386 & 0.19 & - \\
\hline 60 & 17.71 & (E)-Jasmone & 1392 & 0.13 & - \\
\hline 61 & 17.78 & 3-Isopropylbenzaldehyde & 1397 & - & 0.16 \\
\hline 62 & 17.90 & Premnaspirodiene & 1407 & - & 0.09 \\
\hline 63 & 17.98 & $\alpha$-Cedrene & 1412 & - & 0.09 \\
\hline 64 & 18.06 & (E)-Caryophyllene & 1418 & - & 0.18 \\
\hline 65 & 18.31 & Germacrene B & 1438 & 0.08 & - \\
\hline 66 & 18.37 & (E)-Muurola-3,5-diene & 1443 & - & 0.54 \\
\hline 67 & 18.59 & $\alpha$-Guaiene & 1459 & 0.15 & - \\
\hline 68 & 18.61 & (E)-Muurola-4(14),5-diene & 1461 & - & 3.40 \\
\hline 69 & 18.69 & $\alpha$-Macrocarpene & 1467 & - & 0.19 \\
\hline 70 & 18.76 & $\alpha$-Curcumene & 1473 & - & 0.21 \\
\hline 71 & 19.02 & Viridiflorene & 1492 & 0.09 & 0.00 \\
\hline 72 & 19.01 & Epizonarene & 1492 & - & 0.73 \\
\hline 73 & 19.07 & $\beta$-Macrocarpene & 1497 & - & 0.18 \\
\hline 74 & 19.14 & $\beta$-Vetivenene & 1502 & - & 0.11 \\
\hline 75 & 19.24 & Durohydroquinone & 1510 & 0.09 & - \\
\hline 76 & 19.33 & (Z)-Calamenene & 1518 & - & 1.98 \\
\hline 77 & 19.51 & $\alpha$-Dehydro-ar-himachalene & 1533 & - & 0.35 \\
\hline
\end{tabular}


Table 1 (Continued)

\begin{tabular}{|c|c|c|c|c|c|}
\hline $\mathrm{No}^{\mathrm{a}}$ & $\operatorname{Rt}(\min )$ & Compound name & $\mathrm{RI}^{\mathrm{b}}$ & $\%$ E. saligna & \% C. lusitanica \\
\hline 78 & 19.59 & $\beta$-Calacorene & 1539 & - & 0.43 \\
\hline 79 & 19.82 & $\gamma$-Gurjunene & 1558 & 0.05 & - \\
\hline 80 & 19.83 & $\alpha$-Calacorene & 1559 & - & 0.12 \\
\hline 81 & 19.93 & Pogostol & 1567 & 0.08 & - \\
\hline 82 & 20.03 & Spathulenol & 1576 & 0.43 & 0.05 \\
\hline 83 & 20.11 & Caryophyllene oxide & 1582 & - & 0.23 \\
\hline 84 & 20.11 & Globulol & 1582 & 0.17 & - \\
\hline 85 & 20.43 & iso-Leptospermone & 1608 & 3.23 & - \\
\hline 86 & 20.45 & 1,10-di-epi-Cubenol & 1611 & - & 0.35 \\
\hline 87 & 20.51 & $\alpha$-Colocalene & 1616 & - & 0.08 \\
\hline 88 & 20.65 & $\beta$-Gurjunene & 1628 & 0.08 & - \\
\hline 89 & 20.65 & $\beta$-Acoradiene & 1628 & - & 0.36 \\
\hline 90 & 20.75 & (Z)-Cadina-1(6),4-diene & 1637 & - & 0.26 \\
\hline 91 & 20.91 & $\beta$-Eudesmol & 1650 & - & 0.43 \\
\hline 92 & 21.13 & Cadalene & 1670 & - & 0.14 \\
\hline 93 & 21.33 & (Z)-14-nor-Muurol-5-en-4-one & 1688 & - & 1.89 \\
\hline 94 & 21.46 & 10-nor-Calamenen-10-one & 1699 & - & 0.17 \\
\hline 95 & 22.55 & (Z)-5-Hydroxy-calamenene & 1823 & - & 0.08 \\
\hline 96 & 23.61 & Isopimara-9(11),15-diene & 1926 & - & 0.14 \\
\hline 97 & 23.94 & Kaur-15-ene & 1961 & - & 0.03 \\
\hline 98 & 24.26 & Sandaracopimara-8(14),15-diene & 1996 & - & 0.22 \\
\hline 99 & 24.52 & 13-epi-Manool oxide & 2024 & - & 0.27 \\
\hline 100 & 25.37 & Abietadiene & 2115 & - & 0.12 \\
\hline 101 & 25.81 & Nezukol & 2163 & - & 0.68 \\
\hline 102 & 27.35 & (E)-Totarol & 2342 & - & 0.08 \\
\hline
\end{tabular}

$-=$ Absent.

a No $=$ Peak numbers as indicated in Figs. 1 and 2.

b $\mathrm{RI}=$ Retention index.

Table 2

$\mathrm{LC}_{50}$ values $(\% \mathrm{v} / \mathrm{w})$ of essential oils after $24-168 \mathrm{~h}$ of contact with four stored product insects.

\begin{tabular}{|c|c|c|c|c|c|}
\hline \multirow[t]{2}{*}{ Plant EO/Insects ${ }^{\mathrm{a}}$} & \multirow[t]{2}{*}{$N$} & \multicolumn{4}{|l|}{ Time $(\mathrm{h})$} \\
\hline & & 24 & 72 & 120 & 168 \\
\hline \multicolumn{6}{|l|}{ C. lusitanica } \\
\hline T. castaneum & 20 & $0.18(0.17,0.21)^{\mathrm{b}}$ & $0.17(0.15,0.18)$ & $0.13(0.12,0.29)$ & $0.12(0.11,0.14)$ \\
\hline A. obtectus & 20 & $0.11(0.17,0.21)$ & $0.17(0.15,0.18)$ & $0.13(0.12,0.13)$ & $0.12(0.11,0.14)$ \\
\hline S. cerealella & 20 & $0.05(0.03,0.06)$ & $0.02(0.01,0.04)$ & $0.02(0.01,0.04)$ & $0.02(0.01,0.04)$ \\
\hline S. zeamais & 20 & $1.21(0.46,25)$ & $0.52(0.29,4.01)$ & $0.19(0.16,0.26)$ & $0.14(0.12,0.17)$ \\
\hline \multicolumn{6}{|l|}{ E. saligna } \\
\hline T. castaneum & 20 & $0.19(0.16,0.27)$ & $0.17(0.13,0.25)$ & $0.15(0.12,0.29)$ & 0.11 \\
\hline A. obtectus & 20 & 0.02 & 0.001 & 0.001 & 0.001 \\
\hline S. cerealella & 20 & $0.08(0.01,0.15)$ & 0.06 & 0.04 & $0.02(0.01,0.04)$ \\
\hline S. zeamais & 20 & 17 & $0.39(0.27,0.91)$ & $0.39(0.23,3.1)$ & $0.13(0.10,0.17)$ \\
\hline
\end{tabular}

a Twenty unsexed adult insects in 4 replicates, were used for each concentration $(\% \mathrm{v} / \mathrm{w})$.

b Figures in parentheses represent the lower and upper $95 \%$ confidence limits for the $\mathrm{LC}_{50}$ values.

toxic to $S$. zeamais $168 \mathrm{~h}$ post treatment recording a $\mathrm{LC}_{50}$ value of $0.13 \% \mathrm{v} / \mathrm{w}$ (Table 2 ). By comparison, all test insects were susceptible to the oils except $T$. castaneum . The positive controls, crude soya oil and Actelic super ${ }^{\mathrm{TM}}$ were toxic to test insects causing a mortality of 88.5 and $100 \%$ mortality, respectively $72 \mathrm{~h}$ post-contact with treated grains.

\subsection{Space fumigation}

Fumigant toxicity of $C$. lusitanica and E. saligna leaf essential oils against the four test insects resulted in significant essential oil concentration-, insect species- and fumigation duration-dependent insect mortality (ANOVA: $F_{(3,96)}=5.8-197.0$; $\left.{ }^{* * *} P<0.001\right)$. At $10 \mu \mathrm{L} / \mathrm{L}$ air, $C$. lusitanica oil caused 90.6 and $100 \%$ mortality of adult $S$. cerealella and $A$. obtectus, respectively 24 h postfumigation (Fig. 5a). The E. saligna essential oil, at $15 \mu \mathrm{l} / \mathrm{L}$ air, caused 94.7 and $100 \%$ kill for A. obtectus and S. cerealella, respectively, $24 \mathrm{~h}$ post-fumigation (Fig. 5b). C. lusitanica oil was relatively more toxic with 65.8 and $71.4 \%$ mortality in S. zeamais and T. castaneum $168 \mathrm{~h}$ post-fumigation with a higher concentration of $20 \mu \mathrm{l} / \mathrm{L}$ air (Fig. 6a). Similarly at a concentration of $20 \mu \mathrm{l} / \mathrm{L}$ air E. saligna oil caused mor- tality of 61.1 and $92.1 \%$ in S. zeamais and T. castaneum, respectively $168 \mathrm{~h}$ post-fumigation (Fig. $6 \mathrm{~b}$ ).

C. lusitanica oil was highly toxic with $\mathrm{LC}_{50}$ values of 4.08 and $4.71 \mu \mathrm{L} / \mathrm{L}$ air against $A$. obtectus and S. cerealella, respectively $24 \mathrm{~h}$ post-fumigation. The E. saligna leaf essential oil was moderately toxic with $\mathrm{LC}_{50}$ values of 6.71 and 7.02 and $\mu \mathrm{L} / \mathrm{L}$ air for $S$. cerealella and $A$. obtectus, respectively $24 \mathrm{~h}$ post-fumigation. However, C. lusitanica at a concentration of $20 \mu \mathrm{l} / \mathrm{L}$ air was more toxic to $S$. zeamais and $T$. castaneum with $\mathrm{LC}_{50}$ values of 13.54 and $15.28 \mu \mathrm{L} / \mathrm{L}$ air, respectively $168 \mathrm{~h}$ post-fumigation (Table. 3 ).

T. castaneum and $S$. zeamais were still less susceptible to $E$. saligna oil with $\mathrm{LC}_{50}$ values of 9.49 and $15.34 \mu \mathrm{L} / \mathrm{L}$ air, respectively $168 \mathrm{~h}$ post-fumigation (Table. 3 ). The cumulative percentage mortality of all insects tested was higher $168 \mathrm{~h}$ post-fumigation compared to 24 h. $T$. castaneum was tolerant to plant oils as compared to the other insect species tested.

\subsection{Instant repellence}

The results of repellence assay for $C$. lusitanica and E. saligna leaf essential oil against $T$. castaneum, A. obtectus, S. cerealella and S. zeamais are presented in Fig. 7a and b. The plant species, concen- 


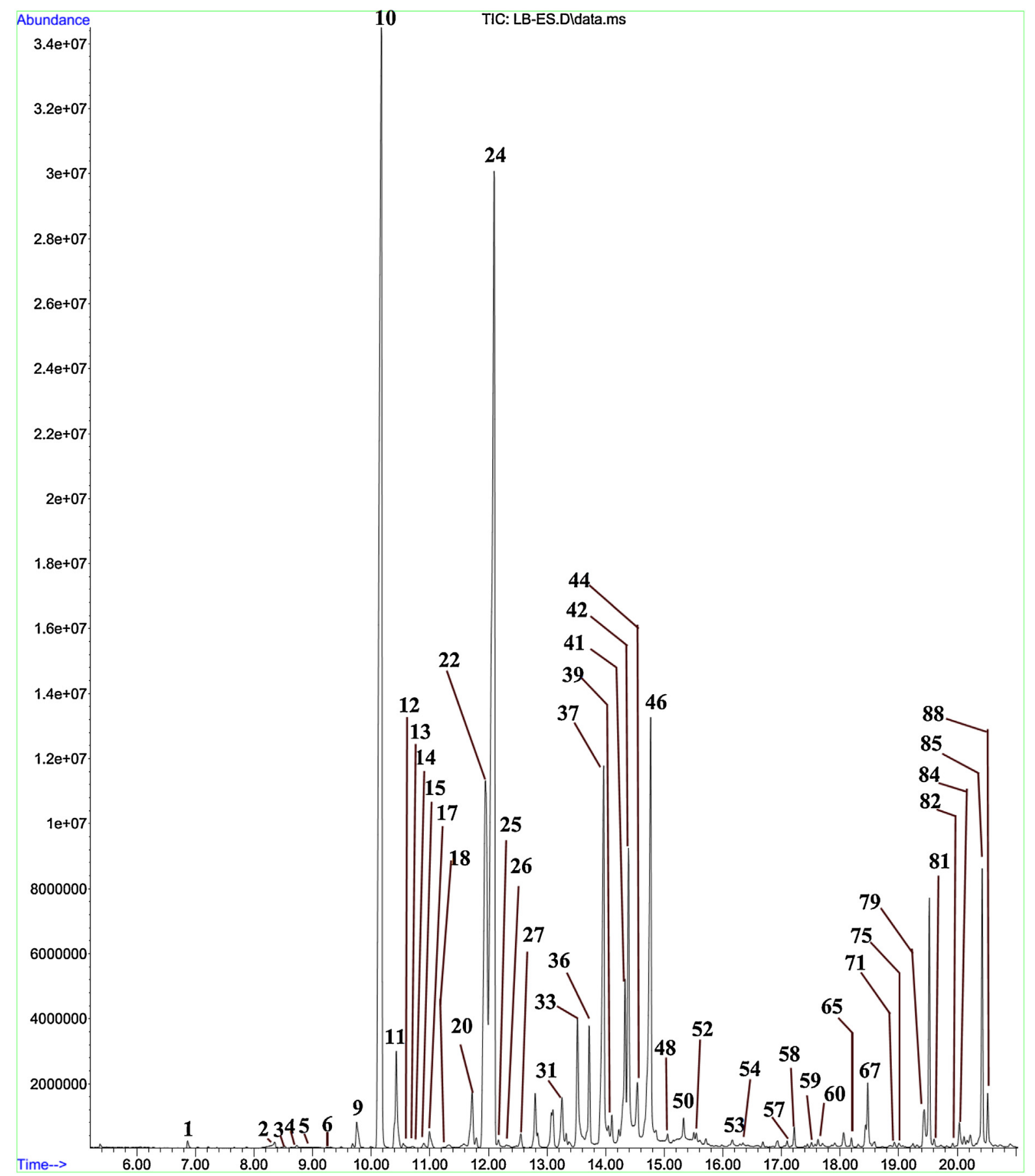

Fig. 1. Representative total ion chromatogram of the leaf essential oil of Eucalyptus saligna. Peaks 1-88 indicate the essential oil components identified (Table 1).

tration of essential applied and time post-treatment significantly influenced the percent repellence of all the test insects (ANOVA: $\left.F_{(3,96)}=2.37-63.83 ;{ }^{* * *} P<0.001\right)$ except $A$. obtectus in which all factors were insignificant (ANOVA: $F_{(3,96)}=0.431-2.42 ; P>0.05$ ).

At $0.20 \% \mathrm{v} / \mathrm{w}$, C. lusitanica leaf essential oil was strongly repellent to $T$. castaneum (92.5\%) but produced low PR values against $A$. obtectus (27.5\%) and S. cerealella (30.0\%) $24 \mathrm{~h}$ after exposure (Fig. 7a). At the same concentration, S. zeamais showed negative (-5.3\%) repellency (attraction) $24 \mathrm{~h}$ after exposure. The PR values for E. saligna leaf essential oil, at $0.20 \% \mathrm{v} / \mathrm{w}$, against $T$. castaneum, A. obtectus, S. cerealella and S. zeamais were $9.3,4.0,1.8$ and $-10 \%$, respectively $24 \mathrm{~h}$ after exposure (Fig. $7 \mathrm{~b}$ ). In $T$. castaneum the PR values increased (65-92.5\%) with dosage $24 \mathrm{~h}$ post treatment with $C$. lusi- tanica oil. However, both C. lusitanica and E. saligna oils produced decreasing PR values of 12 to $-4 \%, 55.5-1.8 \%$ and 38.9 to $-10 \%$ against $A$. obtectus, S. cerealella and S. zeamais, respectively $24 \mathrm{~h}$ post-treatment (Fig. 7a and b). The positive control (DEET-treated grains) produced PR values of 2.5-30.5\% after $24 \mathrm{~h}$ exposure, with low repellence observed against S. zeamais (30.5\%) and T. castaneum (27.5\%) as compared to S. zeamais and S. cerealella. The PR values for negative controls were zero and hence excluded from the results.

\section{Discussion}

The chemical profiles of C. lusitanica and E. saligna essential oils varied qualitatively and quantitatively in relation to the plant 


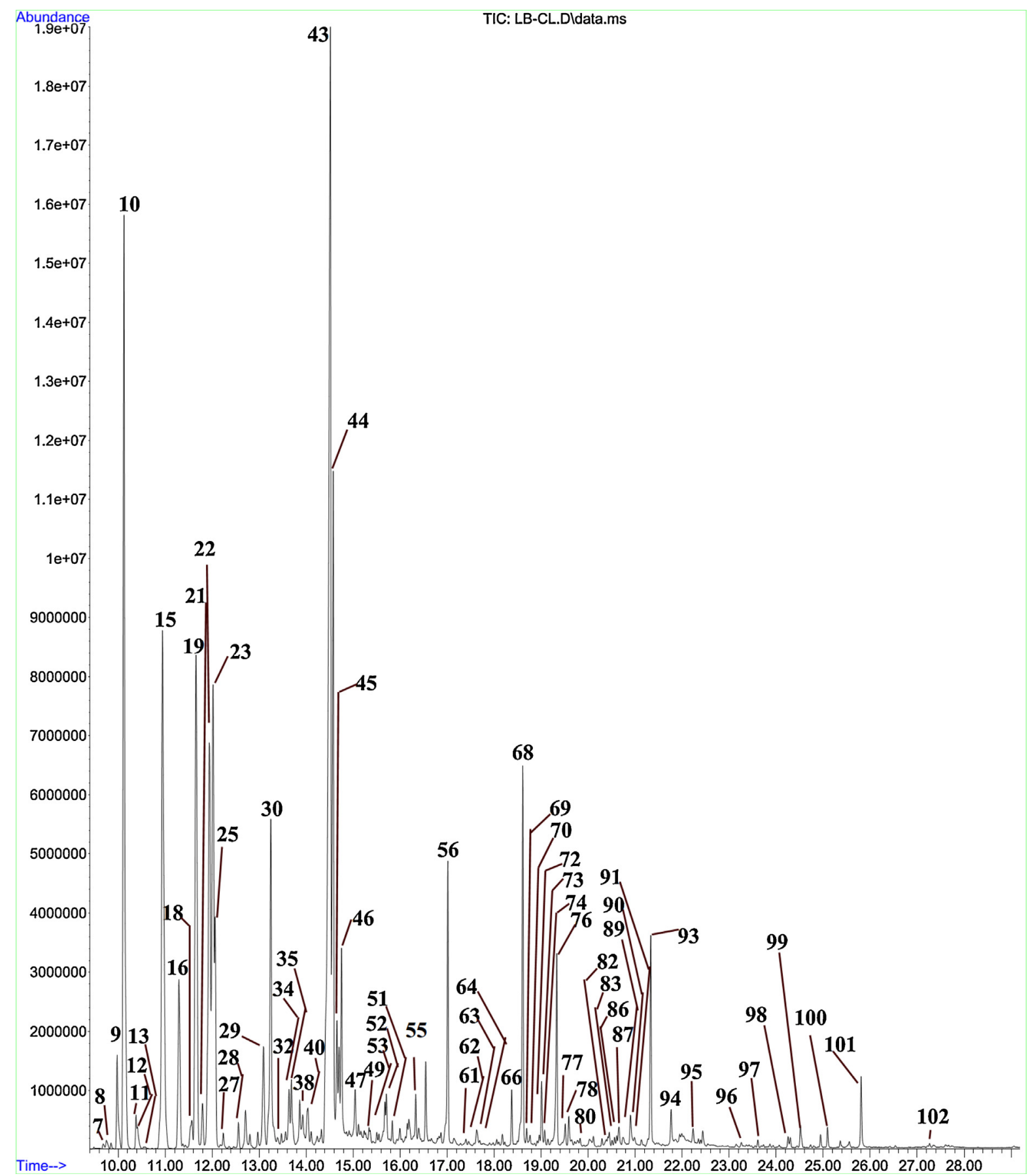

Fig. 2. Representative total ion chromatogram of the leaf essential oil of Cupressus lusitanica. Peaks 7-102 indicate the essential oil components identified (Table 1).

species, but were dominated by monoterpenoids; umbellulone, $\alpha$-pinene and sabinene in $C$. lusitanica and $\alpha$-pinene, 1,8 -cineole, and $o$-cymene in E. saligna oil. Our results are in agreement with previous studies carried out on the essential oil of $C$. lusitanica found in Argentina (Floreani et al., 1982) and Portugal (Carmo and Frazão, 1989; Adams et al., 1997) containing mainly $\alpha$-pinene (6.1-18.0\%), $\beta$-pinene (13.0-16.5\%), $\delta$-3-carene (13-19.4\%), abietadiene (11-24\%), trans-totarol (5.1-6.5) and sabinene (6.7-13.0\%). Whereas the essential oil of $C$. lusitanica collected from Monteverde, Costa Rica, was dominated by $\alpha$-pinene (39.2-82.3\%), limonene (4.2-17.6\%), isobornyl acetate (4.6-9.6\%) and cis-muurola-4,5diene (6.4-6.7\%) (Hassanzadeh et al., 2010) similar plants found in Cameroon are dominated by umbellulone (17-18\%) and germa- crene D (18.5\%) (Kuiate et al., 2006; Teke et al., 2013). Noteworthy, whereas abietadiene and trans-totarol and germacrene D were not detected in the oils in the present study, they were detected in relatively high proportions in the oil obtained from C. lusitanica growing in Portugal (abietadiene (11-24\%)) and trans-totarol (5.1-6.5\%) (Adams et al., 1995) and germacrene D (18.5\%) in the same plant species in Cameroon (Teke et al., 2013).

Similarly, results obtained for E. saligna revealed a chemical composition similar or different from those of other researchers. For instance, E. saligna growing in Cameroon contained mainly $\alpha$-pinene (12.2-39.47\%), cymol (12.7-41.1\%), and 1,8-cineole (9.8-26.2\%) (Tapondjou et al., 2005; Dongmo et al., 2008). Also, Mossi et al. (2011) reported that Cameroonian E. saligna was dom- 
Table 3

$\mathrm{LC}_{50}$ values ( $\mu \mathrm{l} / \mathrm{L}$ air) of essential oils against four stored product insects in space fumigation chambers $24 \mathrm{~h}$ post-fumigation

\begin{tabular}{|c|c|c|c|c|c|}
\hline \multirow[t]{2}{*}{ Plant EO/Insect ${ }^{\mathrm{a}}$} & \multirow[t]{2}{*}{$N$} & \multicolumn{4}{|l|}{ Time (h) } \\
\hline & & 24 & 72 & 120 & 168 \\
\hline \multicolumn{6}{|l|}{ C. lusitanica } \\
\hline T. castaneum & 20 & $19.67(17.85,22.54)^{b}$ & $19.02(17.03,22.13)$ & $15.28(13.81,17.24)$ & $15.28(9.86,78.49$ \\
\hline A. obtectus & 20 & $4.08(3.23,4.77)$ & $4.56(3.71,4.98)$ & $3.61(2.00,4.25)$ & $3.17(0.83,3.99)$ \\
\hline S. cerealella & 20 & $4.71(4.01,5.27)$ & $3.69(2.36,4.29)$ & $3.91(2.88,4.45)$ & $3.76(2.55,4.34)$ \\
\hline S. zeamais & 20 & $29.11(18.11,1139)$ & 20.84 & $17.11(11.82,77.51)$ & 13.54 \\
\hline \multicolumn{6}{|l|}{ E. saligna } \\
\hline T. castaneum & 20 & $16.09(11.96,30.47)$ & $11.47(10.67,12.27)$ & $10.79(8.12,13.30)$ & $9.49(6.43,12.36)$ \\
\hline A. obtectus & 20 & 7.018 & 5.37 & 5.09 & 5.06 \\
\hline S. cerealella & 20 & $6.71(6.25,7.48)$ & $5.03(4.47,5.51)$ & $4.54(3.65,4.87)$ & $6.71(6.25,7.18)$ \\
\hline S. zeamais & 20 & 26.85 & $30.79(23.03,55.58)$ & $20.29(16.78,28.13)$ & 15.34 \\
\hline
\end{tabular}

a Twenty unsexed adult insects in 4 replicates, were used for each concentration $(\% \mathrm{v} / \mathrm{w})$.

b Figures in parentheses represent the lower and upper $95 \%$ confidence limits for the $\mathrm{LC}_{50}$ values.

inated by 1,8 -cineole (45.2\%), p-cymene (34.4\%) and $\alpha$-pinene (12.8\%). However, E. saligna growing in Argentina contained a very high percentage of 1,8 -cineole (93.2\%) and other minor terpenes that include $p$-cymene, limonene, and $\alpha$-terpinene (Toloza et al., 2006). These differences in the chemical composition of essential oils of $C$. lusitanica and E. salgna obtained from the present study and those analyzed in other regions could be attributed to differences in geographical and climatic factors associated with the regions these plants grow and possibly the method of extraction of these oils (Brooker and Kleinig, 2006). Consistent with these suggestions, Barton et al. (1989) observed that in Eucalyptus spp. the percentage of essential oils extracted and their chemical compositions varied widely between species and between individual plants.

Our results from the instant toxicity assay demonstrate that the essential oils obtained from the leaves of $C$. lusitanica and $E$. saligna are moderate to strong insect pest contact toxicants depending on the insect species, duration of exposure and concentration applied. The fact that $C$. lusitanica and E. saligna oils at a concen-
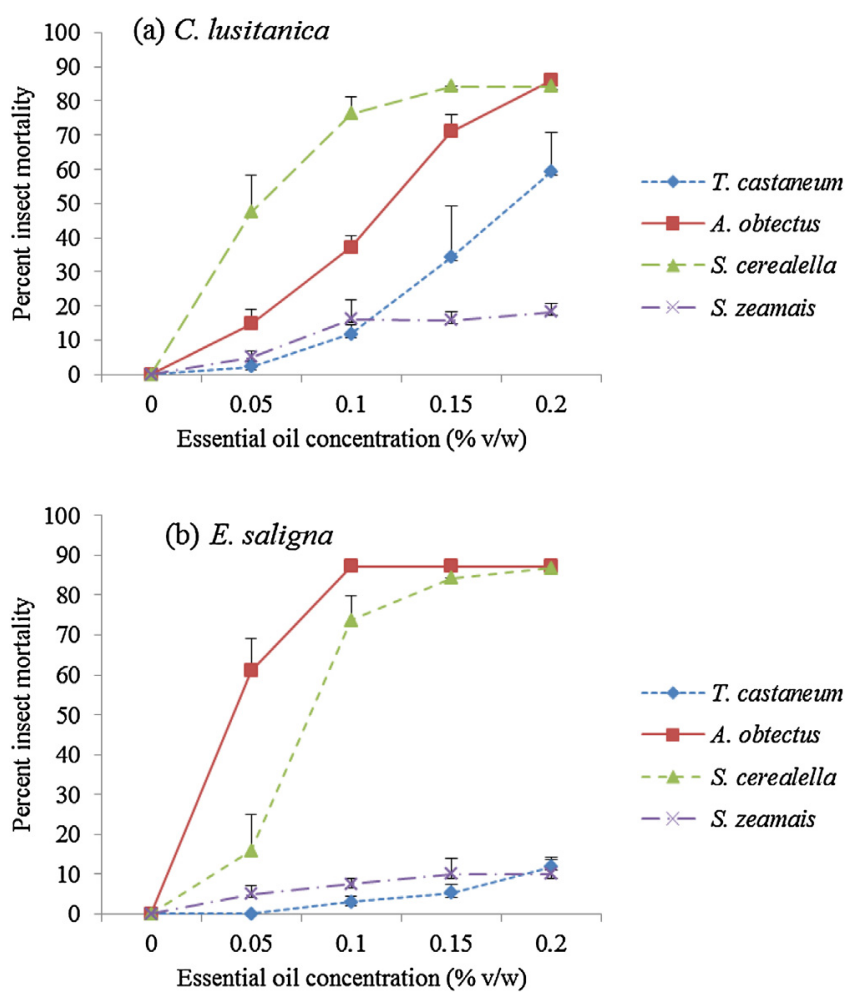

Fig. 3. Percent mortality (Mean $\pm S E, n=4$ ) of four stored product insects after $24 \mathrm{~h}$ of contact with (a) C. lusitanica and (b) E. saligna leaf essential oils. tration of $2.0 \% \mathrm{v} / \mathrm{w}$ caused mortality in all test insects of $58-87 \%$ and $19-90 \%$, respectively $168 \mathrm{~h}$ post-treatment is an indication of the promise the two pesticidal plants hold in pest management. These results are in agreement with other studies where several essential oils and constituents from plants in the Lamiaceae, Verbenaceae, Fabaceae, Cupressaceae and Myrtaceae families have demonstrated variable efficacy from weak to strong contact toxicants against major coleopteran and lepidopteran insect pests (Ngamo et al., 2004; Tapondjou et al., 2005; Ogendo et al., 2008; Mossi et al., 2011). In related studies, plant powders and essential oils from Tephrosia vogelii caused mortality of 83.0-93.7\% in major lepidopteran and coleopteran pests of stored products (Ogendo et al., 2003, 2008). Interestingly, C. lusitanica oil was an effective insecticide against $T$. castaneum causing a mortality of $77.6 \%\left(\mathrm{LC}_{50}\right.$ : $0.13 \% \mathrm{v} / \mathrm{w}) 168 \mathrm{~h}$ post treatment.
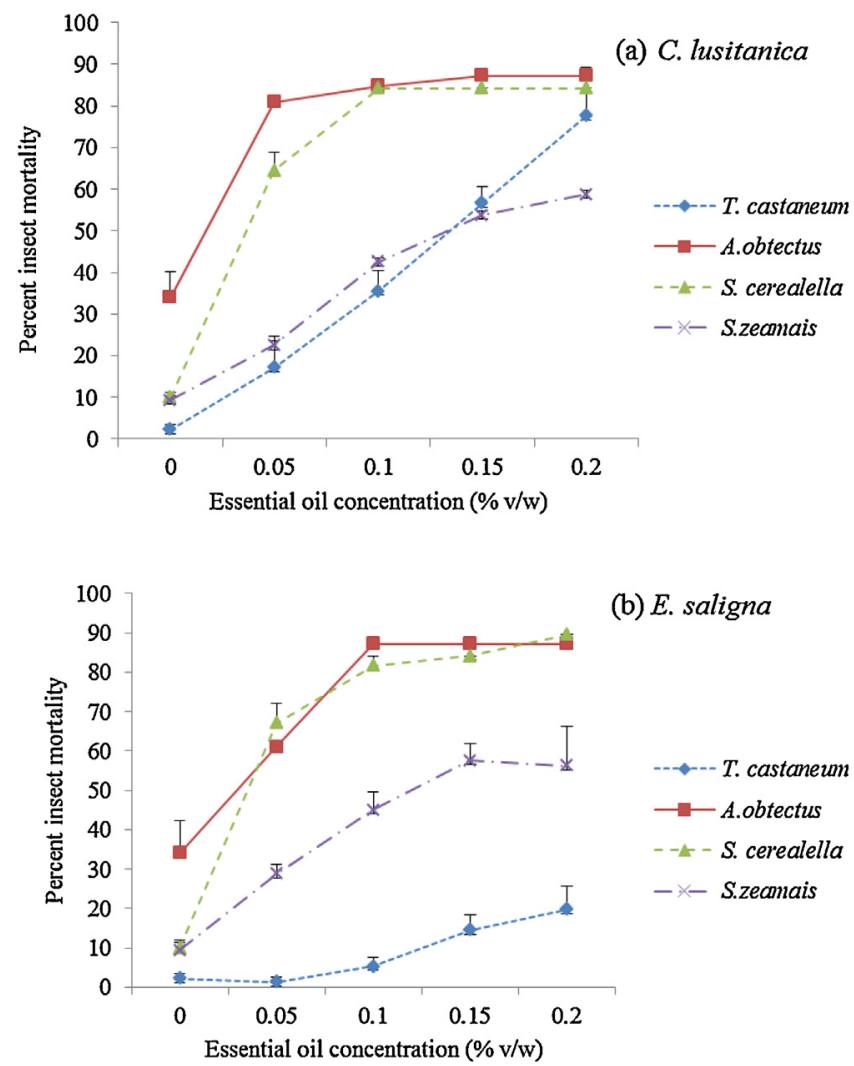

Fig. 4. Percent mortality (Mean \pm SE, $n=4$ ) of four stored product insects after $168 \mathrm{~h}$ of contact with (a) C. lusitanica and (b) E. saligna leaf essential oils. 

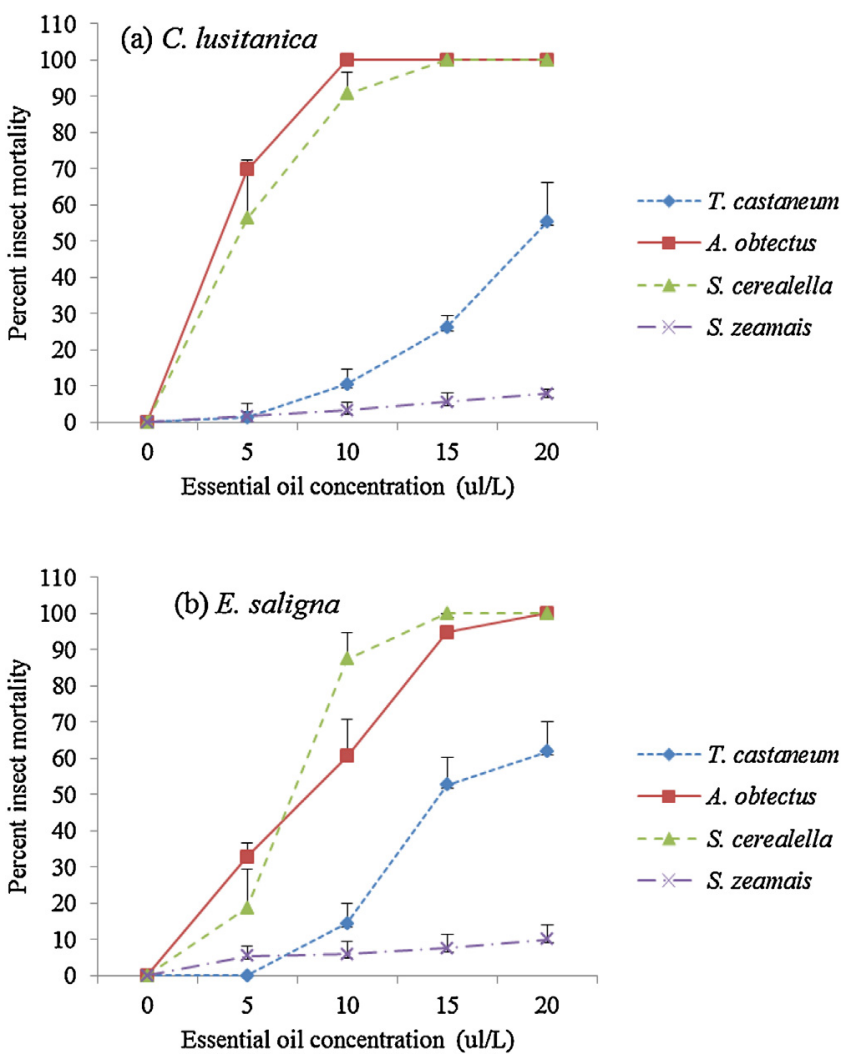

- S. cerealella

$-\times-$ S. zeamais

Fig. 5. Percent mortality (Mean $\pm \mathrm{SE}, n=4$ ) of adult $T$. castaneum, A. obtectus, $S$. cerealella and $S$. zeamais after $24 \mathrm{~h}$ exposure to five concentrations (v/w) of (a) $C$. lusitanica and (b) E. saligna leaf essential oils in space fumigation chambers.

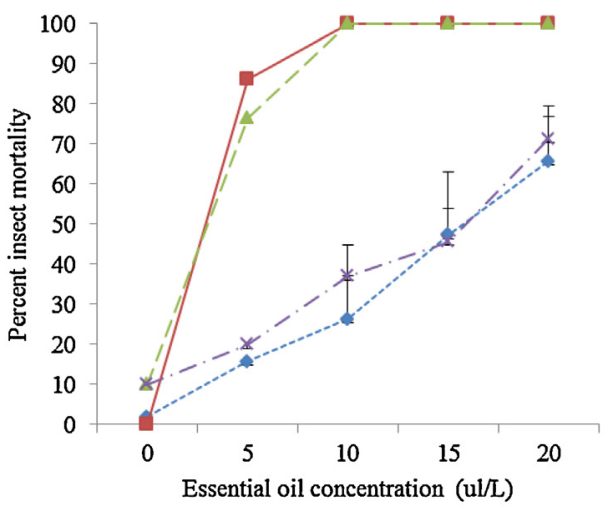

(a) C. lusitanica
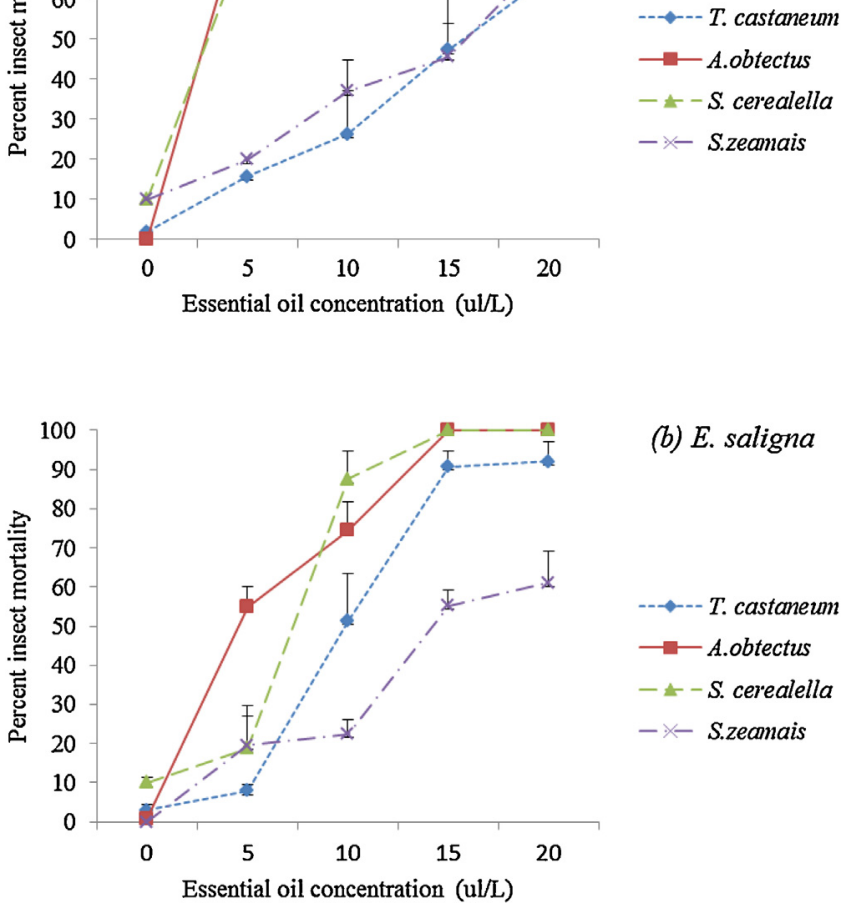

(b) E. saligna
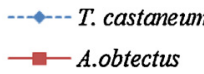

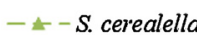

$-x-$ S.zeanais

Fig. 6. Percent mortality (Mean $\pm \mathrm{SE}, n=4$ ) of adult $T$. castaneum, A. obtectus, $S$. cerealella and $S$. zeamais after $168 \mathrm{~h}$ exposure to five concentrations $(\mathrm{v} / \mathrm{w})$ of $(\mathrm{a})$ C. lusitanica and (b) E. saligna leaf essential oils in space fumigation chambers.
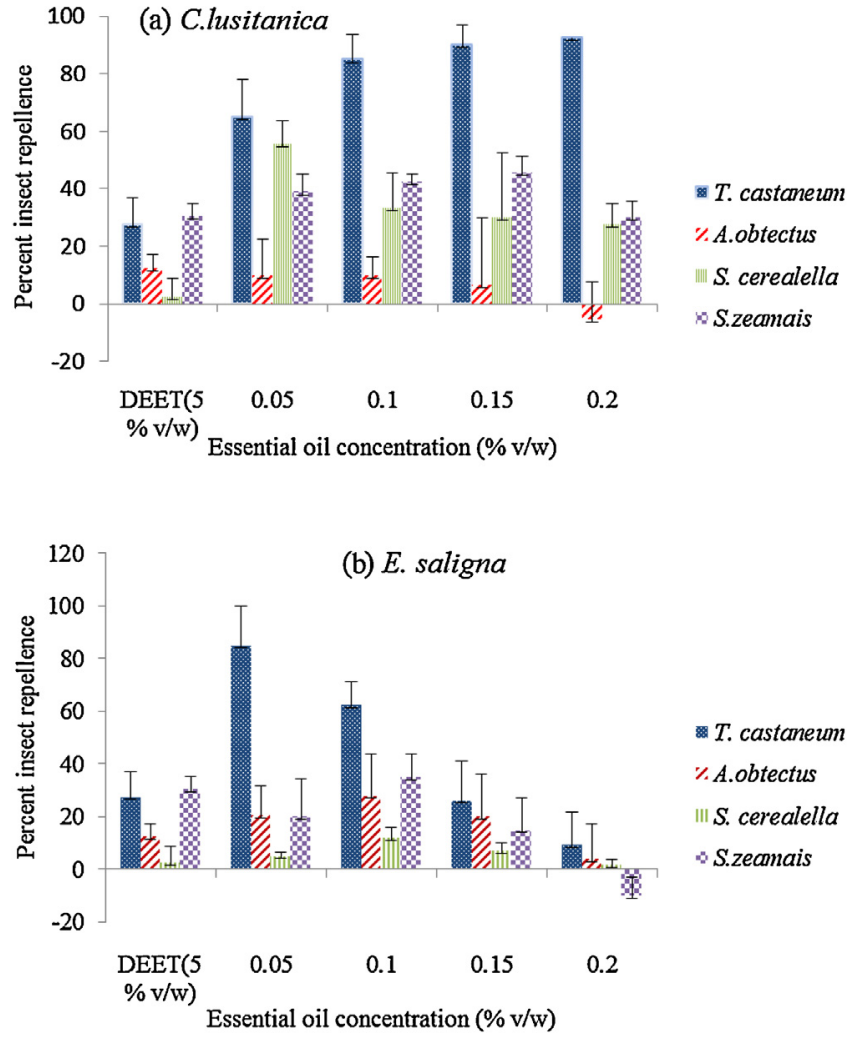

Fig. 7. Percent repellence (Mean $\pm \mathrm{SE}, n=4$ ) of adult $T$. castaneum, A. obtectus, $S$. cerealella and $S$. zeamais after $24 \mathrm{~h}$ exposure to (a) C. lusitanica and (b) E. saligna leaf essential oils in untreated-treated choice bioassay system.

In previous studies, Ngamo et al. (2004) showed that essential oils of Annona senegalensis (Annonaceae), Eucalyptus citriodora, Ecalyptus saligna(Myrtaceae), Lippia rugosa(Verbenaceae) and Ocimum gratissimum (Lamiaceae) to had significant insecticidal activity against S. zeamais, but $50 \%$ of the efficacy was lost for all the plants except $A$. senegalensis 8 days post treatment. Tapondjou et al. (2005) demonstrated that oils from E. saligna and Cupressus sempervirens leaves assayed by impregnation on filter paper discs or coating onto maize grains showed that these chemicals caused significant mortality of S. zeamais and Tribolium confusum. Eucalyptus oil was more toxic than Cupressus oil to both insect species $\left(\mathrm{LD}_{50}=0.36 \mathrm{~mL} \mathrm{~cm}^{-2}\right.$ for S. zeamais and $0.48 \mathrm{~mL} \mathrm{~cm}^{-2}$ for T. confusum) and was more toxic to $S$. zeamais on maize ( $\mathrm{LD}_{50}=38.05 \mathrm{~mL} / 40 \mathrm{~g}$ grain). It is possible that $\alpha$-pinene (39.47\%) and cymol (31.1\%) which were major constituents in E. saligna essential oils were responsible for the higher toxicity.

Furthermore, Mossi et al. (2011) was able to demonstrate that essential oils of three Eucalyptus species caused mortality of $100 \%$ in S. zeamais at doses of 65, 100 and $400 \mu \mathrm{L}$ for Eucalyptus dunnii, E. saligna and Eucalyptus benthamii, respectively. The $\mathrm{LD}_{50}$ values of the three oils were 25. 03, 37. 93 and $121.09 \mu \mathrm{L}$ for E. dunnii, $E$. saligna and $E$. benthamii, respectively on filter papers impregnated with test essential oils. The authors were able to conclude that variations in toxicity of essential oils from the different species of Eucalyptus related to the concentration of 1,8-cineole and largely responsible for the oil toxicity (Duke, 2004).

The fact that plant oils were toxic at concentration of 4.08-7.02 $\mu \mathrm{l} / \mathrm{L}$ air against $A$. obtectus and $S$. cereallela respectively $24 \mathrm{~h}$ post fumigation and $71.4-100 \%$ mortality in all test insects except $S$. zeamais $168 \mathrm{~h}$ post fumigation demonstrate their applicability in grain fumigation. The results of our study are mostly in agreement with the results of several previous investigators. Previous studies have demonstrated that $T$. vogelii essential oils pro- 
duced strong contact (up to $83 \%$ kill) and fumigant toxicities against four coleopteran pests of stored cereal and legume grains including insects feeding on pigeon pea and chickpea (Minja et al., 2002; Papachristos and Stamopoulos, 2004; Ogendo et al., 2008). Lee et al. (2004) showed that essential oils from Eucalyptus nicholii, Eucalyptus codonocarpa, Eucalyptus blakelyi, Callistemon sieberi, Melaleuca fulgens and Melaleuca armillaris were effective against Sitophilus oryzae adults with $\mathrm{LD}_{50}$ values of $19.0-30.6 \mathrm{~mL} / \mathrm{L}$ air but were less toxic to T. castaneum and Rhyzopertha dominica. Toloza et al. (2006) showed that essential oils of Myrcianthes cisplatensis, Eucalyptus cinerea, Eucalyptus viminalis and E. saligna had knock-down time $\left(\mathrm{KT}_{50}\right)$ of 1.3-17.4 min against head lice, (Pediculus humanus capitis). Similarly essential oil constituents 1,8-cineole, anisole and benzyl alcohol had KT50 values of $12.0,14.9$, and $17.4 \mathrm{~min}$, respectively against the same pest. In other studies, Rosman et al. (2007) found 1,8-cineole, camphor, linalool, thymol, borneol, extracted from Lavandula angustifolia, Rosmarinus officinalis, Thymus vulgaris and Laurus nobilis to cause up to $100 \%$ mortality in S. oryzae and $R$. dominica when applied for $24 \mathrm{~h}$ at the lowest dose $(0.1 \mathrm{~mL} / 720 \mathrm{~mL}$ vol.). However in T. castaneum no oil compounds achieved more than $20 \%$ mortality after exposure for $24 \mathrm{~h}$, even with the highest dose (100 mL/720 mL volume). In related studies, Ogendo et al. (2008) reported that Ocimum americanum leaf essential oil at $50 \mu \mathrm{LL}^{-1}$ air, 7 days exposure and $120 \mathrm{~h}$ post fumigation time, caused 66,95 and $100 \%$ kill of $T$. castaneum, S. oryzae and R. dominica, respectively.

Alzogaray et al. (2011) found essential oils extracted from 11 species of the genus Eucalyptus and two of their hybrids to have fumigant activity against first instar Blattella germanica with lowest $\mathrm{KT}_{50}$ values of 57.9-161.4 min by exposing nymphs to vapors emitted by $50 \mu \mathrm{L}$ of essential oil in a closed container. The $\mathrm{KT}_{50}$ values of monoterpenes from same oils were 38.8 for $\alpha$-pinene, 55.3 for 1,8 -cineole, 175.6 for $p$-cymene, and $178.3 \mathrm{~min}$ for $\gamma$-terpinene. The results of this study and pervious reports prove that plant oils have fumigant efficacy comparable to methyl bromide's recommended rate of $30-50 \mathrm{~g} \mathrm{M}^{-3}$ grain, $50 \mu \mathrm{LL}^{-1}$ air for the highly active Labiatae species oil, ZP51 and $50-150 \mathrm{mg} \mathrm{L}^{-1}$ for allyl acetate to achieve $94.0-100 \%$ mortality of all insect pests of stored cereal and legume grains (Busvine, 1980; Shaaya et al., 1997; Rajendran and Muralidharan, 2005).

The reported moderate to strong contact and fumigant toxicity of the essential oils tested in the present study could be attributed to individual and/or blend effects of bioactive chemical constituents contained in the essential oils (Arriaga et al., 2005; Ogendo et al., 2008). Contact toxicity of essential oils against insect pests of stored products has been associated previously to presence of 1,8cineole, eugenol, methyl eugenol, limonene and $\alpha$-pinene among other bioactive essential oil constituents (Bekele and Hassanali, 2001; Huang et al., 2002). Moreover, essential oils constituents 1,8-cineole, camphor, linalool, thymol, borneol, limonene $\alpha$-pinene $p$-cymene, and $\gamma$-terpinene have been associated with fumigant toxicity against various insect pests (Shaaya et al., 1991; Rosman et al., 2007; Alzogaray et al., 2011).

The results of contact and fumigant toxicity in the current study seems lower than those found by other researchers possibly due to differences in concentrations used and major chemical constituents of test plant essential oils. In the current study, the C. lusitanica oil contained mainly umbellulone (18.38\%), $\alpha$-pinene $(9.97 \%)$, sabinene $(8.16 \%)$ and limonene $(7.91 \%)$ whereas the E. saligna oil was dominated by $\alpha$-pinene $(24.40 \%), 1,8$-cineole $(24.26 \%)$, $o$-cymene(9.92\%) and $\alpha$-terpineol (8.81\%). The concentrations of 1,8-cineole was low in E. saligna and event absent in $C$. lusitanica which could have contributed to the variable efficacy as compared to other studies (Ngamo et al., 2004, Tapondjou et al., 2005; Mossi et al., 2011; Ogendo et al., 2013). These results, and those reported earlier, indicate that the insecticidal activity of the essen- tial oils varies depending on the stage of the insect development, the species and the plant origin of the essential oil (Brooker and Kleinig, 2006).

Moreover, the insecticidal activity of eucalyptus oils has been associated with components such as 1,8-cineole, citronellal, citronellol, citronellyl acetate, $p$-cymene, eucamalol, limonene, linalool, $\alpha$-pinene, $\gamma$-terpinene, $\alpha$-terpineol, alloocimene, and aromadendrene (Duke, 2004; Batish and Kohli, 2008). However, it has also been suggested that individual substances contained in essential oils might have a mutual synergistic effect in evoking biological activity (Murungi et al., 2013). Lee et al. (2003) proved there was contact toxicity through the insect cuticle, and fumigant toxicity through the respiratory and digestive systems. Ryan and Byrne (1988) suggested that the toxic effect of essential oil constituents may be attributed to reversible competitive inhibition of acetylcholinesterase by occupation of the hydrophobic site of the enzyme's active center.

The results of repellency assay of essential oils of $C$. lusitanica and $E$. saligna showed variable responses from test insects. $C$. lusitanica essential oil was a strong repellent against $T$. castaneum at concentration of $0.20 \% \mathrm{v} / \mathrm{w}$ after $24 \mathrm{~h}$ of exposure and moderately repellent against $S$. zeamais but a weak repellent against the remaining insects. These results are in agreement with a previous study in which powders and essentials oils and constituents were strongly repellent against insect pests (Chebet et al., 2013). Chebet et al. (2013) demonstrated that grains treated with crude powders of Tephrosia vogelii and Azadrachta indica were equally the most repellent (PR values: 88-90\%) against adult Prostephantus truncatus followed by Lantana camara (PR 73\%).

In a related study, Toloza et al. (2006) showed that essential oils from M. cisplatensis, E. cinerea, E. viminalis and E. saligna Mentha pulegium and its benzyl alcohol component exhibited repellency indices of 75.5 and $57.8 \%$, respectively against head lice, (Pediculus humanus capitis). Liang et al. (2013) screening for repellency against the $T$. castaneum and fourteen Chinese medicinal herbs showed that the essential oils from Curcuma longa, Epimedium pubescens, Lindera aggregate, Nardostachys chinensis, Schizonepeta tenuifolia, Zanthoxylum schinifolium, and Zanthoxylum officinale at doses of $8.5 \mu \mathrm{lcm}^{-2}$ after $2 \mathrm{~h}$ exhibited strong repellency against the pest(PR 37-94\%). The repellence was associated with chemical constituents such as menthol, borneol, and eudesmol which showed repellency against the red flour beetles but weaker than DEET at lower concentrations.

The observed repellent activity could partly be attributed to the presence of monoterpenes and sesquiterpenes which are wellknown repellents of phytophagous insects by acting in the vapour form on the olfactory receptors of these insects (Lee et al., 2003; Wang et al., 2006). The highly repellent effects of plant essential oil constituents such as $\alpha$-pinene 1, 8-cineole, citronellol, eugenol, camphor, terpineol, limonene, geranial, neral, $(E)$-anethole have been demonstrated by other researchers (Tapondjou et al., 2005; Toloza et al., 2006; Mossi et al., 2011; Liu et al., 2011; Nivea et al., 2013). Similarly in the current study, C. lusitanica essential oil main constituents (umbellulone, $\alpha$-pinene and sabinene) and E. saligna ( $\alpha$-pinene, 1,8-cineole, and $o$-cymene) could have contributed to the repellent activity of the two plants. However, minor essential constituents may contribute synergistically to the overall repellent activity of the major constituents (Mossi et al., 2011; Liu et al., 2011; Akhtar et al., 2012).

It is also evident that $C$. lusitanica and E. saligna essential oils are weak repellents against A. obtectus, S. zeamais and S. cerealella $24 \mathrm{~h}$ post-exposure. The results indicate also that repellence decreased with dosage and even negative repellence (attraction) observed. Similar results trend were observed by Wambua et al. (2011) who reported a dose- and exposure time-dependent negative repellence (attraction) of Helicoverpa armigera larvae to chickpea leaves treated with aqueous extracts of T. vogelii. Ogendo et al. (2003) 
reported that maize grains admixed with Actellic Super ${ }^{\mathrm{TM}} 2 \%$ dust registered negative $P R$ values against $S$. zeamais due to the arrestment of test insect by the chemical. In similar studies, Ogendo et al. (2008) reported eugenol to produced PR values in C. chinensis that decreased with dosage of extract. The major cause of the negative PR values was possibly due to the high contact toxicity of eugenol (Huang et al., 2002) against C. chinensis. C. lusitanica and E. saligna essential oils provide nothing significant as far as an effective repellent is concerned. However, negative repellence(attraction) could find a place in insect pest control especially in the push-pull strategy in integrated pest management where a protected source (crop) is unsuitable to pest (Push) while luring towards an attractive source (Pull) from where the pests are subsequently removed or killed avoiding residues in crop (Cook et al., 2007)

The results obtained from this study provide the scientific rationale for use of $C$. lusitanica and E. saligna essential oils and constituents as insecticides and repellents in the protection of stored product insect pests. The essential oils may be used as aromatized powders in contact toxicity. Since essential oils are already volatile substances they may be applied as tablets/encapsulated formulations (similar to done to phosphine) and aerosols in fumigation and repellence compared to methyl bromide and phosphine. Moreover, provided with a proper formulation and dosage, the plant essential oils may be exploited for use against insect infestation at the small scale farmer's level since they may be more effective and less cumbersome than application of dangerous synthetics. Therefore, if the problem of cost-effective commercial production and formulation can be solved, the essential oils tested could find a place in IPM strategies, especially where the emphasis is on environmental and food safety and on replacing the more dangerous synthetic repellents and insecticides.

\section{Conflict of interest}

The authors of this manuscript are not in the know of any personal and institutional affiliations, financial support or membership that might be perceived as affecting the objectivity of this manuscript.

\section{Acknowledgements}

The authors are grateful to Inter-Universities Council of East Africa (IUCEA) and Lake Victoria Research Initiative, Egerton University and National Council for Science, Technology and Innovation (Grant No. NCST/5/003/3) for funding this study. We wish also to thank the International Centre of Insect Physiology and Ecology (ICIPE) for providing GC-MS analysis equipment and Mr. Xavier Cheseto and Mr Onesmus K. Wanyama of the same institution for providing technical support.

\section{References}

Abbott, W.S., 1925. A method of computing the effectiveness of an insecticide. J. Econ. Entomol. 18, 265-267.

Abay, G., Karakoç, Ö.C., Tüfekçi, A.R., Koldas, S., Demirtas, I., 2012. Insecticidal activity of Hypnum cupressiforme (Bryophyta) against Sitophilus granarius (Coleoptera: Curculionidae). J. Stored Prod. Res. 51, 6-10.

Adams, R.P., Zanoni, T.A., Lara, A., Barrero, A.F., Cool, L.G., 1997. Comparisons among Cupressus arizonica Greene, C. benthamii Endl, C. lindleyi Klotz. ex Endl. and C. lusitanica Mill. using essential oils and DNA fingerprinting. J. Essent. Oil Res. 9, 303-309.

Akhtar, Y., Pages, E., Stevens, A., Bradbury, R., da Camara, C.A.G., Isman, M.B., 2012. Effect of chemical complexity of essential oils on feeding deterrence in larvae of the cabbage looper. Physiol. Entomol. 37, 81-91.

Alzogaray, R.A., Lucia, A., Zerba, E.N., Masuh, H.M., 2011. Insecticidal activity of essential oils from eleven Eucalyptus spp. and two hybrids: lethal and sub lethal effects of their major components on Blattella germanica. J. Econ. Entomol. 104, 595-600.
Arriaga, A.M.C., Magalhães, F.E.A., Feitosa, E.M.A., Malcher, G.T., Andrade-Neto, M., Nascimento, R.F., 2005. Composition of the essential oil of Tephrosia egregia Sandw. J. Essen. Oil Res. 17, 451-452.

Asawalam, E.F., Emosairue, S.O., Hassanali, A., 2006. Bioactivity of Xylopia aetiopica (Dunal) a rich essential oil constituents on maize weevil Sitophilus zeamais Motch. (Coleoptera: Curculionidae). Electron. J. Environ. Agric. Food Chem. 5, 1195-1204.

Athanassiou, C.G., Kavallieratos, N.G., Evergetis, E., Katsoula, A., Haroutounian, S.A., 2013. Insecticidal efficacy of silica gel with Juniperus oxycedrus ssp. oxycedrus (Pinales: Cupressaceae) essential oil against Sitophilus oryzae (Coleoptera: Curculionidae) and Tribolium confusum (Coleoptera: Tenebrionidae). J. Econ. Entomol. 106, 1902-1910.

Ayvaz, A., Sagdic,O, Karaborklu, S., Ozturk, I., 2010. Insecticidal activity of the essential oils from different plants against three stored-product insects. J. Insect Sci. 10, 21-23.

Barton, A.F.M., Tjandra, J., Nicholas, P.G., 1989. Chemical evaluation of volatile oils in Eucalyptus species. J. Agric. Food Chem. 37, 1253-1257.

Batish, D.R., Kohli, R.K., 2008. Eucalyptus essential oil as a natural pesticide. For. Ecol. Manage. 256, 2166-2174

Bekele, J., Hassanali, A., 2001. Blend effects in the toxicity of the essential oil constituents of Ocimum kilimandscharicum and 0 . kenyense (Labiatae) on two post-harvest insect pests. Phytochemistry 57, 385-391.

Bett, P.K., Deng, A.L., Ogendo, J.O., Kamatenesi-Mughisha, M., Mihale, J.M., 2013. Toxic and repellent properties of Cupressus lusitanica and Eucalyptus saligna essential oils against Callosobrochus chinensis and Sitophilus zeamais. In: Ogendo, J.O., Lukhoba, C.W., Bett, P.K., Machocho, A.K. (Eds.), Proceedings of the First International Conference on Pesticidal Plants Volume 1 (August, 2013). ADAPPT-Network, Egerton University, pp. 121-123.

Brooker, M.I.H., Kleinig, D.A., 2006. Field Guide to Eucalyptus, vol. 1., Third edition Bloomings, Melbourne, South-eastern Australia.

Busvine, R.J., 1980. Statistical principles of detection and measurement of resistance correction for control mortality, FAO Plant Protection Paper 21, Recommended methods for measurement of pest resistance to pesticide. <http:// sleakfreak.ath.ex:81/3wdev/INPHO/VLIBRARY/X0048E0M.HTM>.

Campbell, J.F., Toews, M.D., Arthur, F.H., Arbogast, R.T., 2010. Long term monitoring of Tribolium castaneum populations in two flour mills: rebound after fumigation. J. Econ. Entomol. 103, 1002-1011.

Carmo, M.M., Frazão, S., 1989. The essential oil of Cupressus lusitanicus Mill. Flavor Fragr. J. 4, 185-186.

Chebet, F., Deng, A.L., Ogendo, J.O., Kamau, A.W., Bett, P.K., 2013. Bioactivity of selected plant powders against Prostephanus truncatus (Coleoptera: Bostrichidae) in stored maize grains. Plant Prot. Sci. 49, 34-43.

Cook, S.M., Khan, Z.R., Pickett, J.A., 2007. The use of push-pull strategies in integrated pest management. Annu. Rev. Entomol. 52, 375-400.

Deng, A.L., Ogendo, J.O., Owuor, G., Bett, P.K., Omolo, E.O., Kamatenesi-Mugisha, M., Mihale, J.M., 2009. Factors determining the use of botanical insect pest control methods by small-holder farmers in the Lake Victoria Basin, Kenya. Afr. J. Environ. Sci. Technol. 3, 108-115.

Dongmo, P.M.J., Ngoune, L.T., Dongmo, B.N., Kuiate, J., Amvam Zollo, P.H., Menut, C., 2008. Antifungal potential of Eucalyptus saligna and Eucalyptus camaldulensis essential oils from Cameroon against Phaeoramularia angolensis. Eur. J. Sci. Res. 24, 348-357.

Duke, J.A., 2004. Dr. Duke's Phytochemical and Ethnobotanical Databases. [Online] (2004). Available: <http://www.ars-grin.gov/duke/>.

Finney, D.J., 1971. Probit Analysis, 3rd ed. Cambridge University Press, London.

Floreani, S.A., Retamar, J.A., Gros, E.G., 1982. Terpenoids of essential oils from species of Cupressus. An. Assoc. Quim. Argentina 70, 663-667.

Hassanzadeh, S.L., Tuten, J.A., Vogler, B., Setzer, W.N., 2010. The chemical composition and antimicrobial activity of the leaf oil of Cupressus lusitanica from Monteverde, Costa Rica. Pharmacogn. Res. 2, 19-21.

Huang, Y., Ho, S.H., Lee, H.C., Yap, Y.L., 2002. Insecticidal properties of eugenol, isoeugenol and methyleugenol and their effects on nutrition of Sitophilus zeamais Motsch. (Coleoptera: Curculionidae) and Tribolium castaneum (Herbst) (Coleoptera: Tenebrionidae). J. Stored Prod. Res. 38, 403-412.

Kamatenesi-Mugisha, M., Buyungo, J.P., Ogwal, P., Kasibante, A., Deng, A.L., Ogendo, J.O., Mihale, J.M., 2013. Oral acute toxicity study of selected botanical pesticide plants used by subsistence farmers around the Lake Victoria Basin. Afr. J. Environ. Sci. Technol. 7, 93-101.

Karakoç, Ö.C., Gökçe, A., Telci, I., 2006. Fumigant activity of some plant essential oils against Sitophilus oryzae L., Sitophilus granarius L. (Col.: Curculionidae) and Acanthoscelides obtectus Say (Col.: Bruchidae). Turk. J. Entomol. 30, 123-135.

Kariuki, S.T., Kariuki, J.M., Ogendo, J.O., Bett, P.K., 2013. Evaluation of Girardinia diversifolia as a potential bio-pesticide in Kenya. In: Ogendo, J.O., Lukhoba, C.W., Bett, P.K., Machocho, A.K. (Eds.), Proceedings of the First International Conference on Pesticidal Plants Volume 1 (August, 2013). ADAPPT-Network: Egerton University, pp. 47-50

Kokwaro, J.O., Johns, T., 1998. Luo Biological Dictionary. East African Educational Publishers, Nairobi.

Koona, D., 2005. Extracts from Tephrosia vogelii for protection of stored legume seeds against damage by three bruchid species. Ann. Appl. Biol. 147, 43-48

Kuiate, J.R., Bessiére, J.M., Vilarem, G., Amvam Zollo, P.H., 2006. Chemical composition and antidermatophytic properties of the essential oils from leaves, flowers and fruits of Cupressus lusitanica Mill. from Cameroon. Flavor Frag. J. 21, 693-697. 
Leatemia, J.A., Isman, M.B., 2004. Toxicity and antifeedant activity of crude seed extracts of Annona squamosa (Annonaceae) against lepidopteran pests and natural enemies. Int. J. Trop. Insect Sci. 24, 150-158.

Lee, S., Peterson, C.J., Coats, J.R., 2003. Fumigation toxicity of monoterpenoids to several stored product insects. J. Stored Prod. Res. 39, 77-85.

Lee, B.H., Annis, C.P., Tumaalii, F., Choi, W.S., 2004. Fumigant toxicity of essential oils from the Myrtaceae family and 1,8-cineole against 3 major stored-grain insects. J. Stored Prod. Res 40, 553-564.

Liang, Y., Lu, J., Xu, S., Zhao, N.N., Zhou, L., Cheng, J., Liu, Z.L., 2013. Evaluation of repellency of some Chinese medicinal herbs essential oils against Liposcelis bostrychophila (Psocoptera: Liposcelidae) and Tribolium castaneum (Coleoptera: Tenebrionidae). J. Econ. Entomol. 106, 513-519.

Liu, Z.L., Yu, M., Li, X.M., Wan, T., Chu, S.S., 2011. Repellent activity of eight essential oils of Chinese medicinal herbs to Blattella germanica L. Rec. Nat. Prod. 5 , 176-183.

Minja, E.M., Karutu, O.M., Silim, S.N., 2002. Efficacy of Tephrosia vogelii crude leaf extract on insect feeding on pigeon pea in Kenya. Int. Chickpea and Pigeonpea Newslett. 9, 49-51.

Mohan, S., Fields, P.G., 2002. A simple technique to assess compounds that are repellent or attractive to stored-product insects. J. Stored Prod. Res. 38, 23-31.

Mossi, A.J., Astolfi, V., Kubiak, G., Lerin, L., Zanella, C., Toniazzo, G., de Oliveira, D., Treichel, H., Devilla, I.A., Cansiana, R., Restelloa, R., 2011. Insecticidal and repellency activity of essential oil of Eucalyptus sp. against Sitophilus zeamais Motschulsky (Coleoptera, Curculionidae). J. Sci. Food Agric. 91, 273-277.

Murungi, L.K., Kirwa, H., Torto, B., 2013. Differences in essential oil content of berries and leaves of Solanum sarrachoides (Solanaceae) and the effects on oviposition of the tomato spider mite (Tetranychus evansi). Ind. Crops Prod. 46, 73-79.

Ngamo, Tinkeu L.S., Goudoum, A., Ngassoum, M.B., Mapongmetsem, P.M., Kouninki, H., Hance, T., 2004. Persistance of the insecticidal activity of five essential oils on the maize weevil Sitophilus zeamais (Motsch.) (Coleoptera: Curculionidae), Commun. Agric. Appl. Biol. Sci. 69 (3), 145-147.

Nivea, M.S.G., de Oliveira, J.V., Navarro, D.M.A.F., Dutra, K.A., da Silva, W.A., Wanderley, M.J.A., 2013. Contact and fumigant toxicity and repellency of Eucalyptus citriodora Hook., Eucalyptus staigeriana F., Cymbopogon winterianus Jowitt and Foeniculum vulgare Mill. essential oils in the management of Callosobruchus maculatus (F.) (Coleoptera: Chrysomelidae, Bruchinae). J. Stored Prod. Res. 54, 41-47.

Nukenine, E.N., 2010. Stored product protection in Africa: past, present and future. In: Proceedings of the 10 th International Working Conference on Stored Product Protection, Julius-Kuhn-Archiv 2010, pp. 26-41.

Ogendo, J.O., Belmain, S.R., Deng, A.L., Walker, D.J., 2003. Comparison of toxic and repellent effects of Lantana camara with Tephrosia vogelii Hook and a synthetic pesticide against Sitophilus zeamais Motsculsky (Coleoptera: Curculionidae) in stored maize grain. Insect Sci. Appl. 23, 127-135.

Ogendo, J.O., Kostyukovsky, M., Ravid, U., Matasyoh, J.C., Deng, A.L., Omolo, E.O. Kariuki, S.T., Shaaya, E., 2008. Bioactivity of Ocimum gratissimum oil and two constituents against five insect pests attacking stored food products. J. Stored Prod. Res. 44, 328-334.

Ogendo, J.O., Deng, A.L., Birech, R.J., Bett, P.K., 2012. Plant-based products as control agents of stored-product insect pests in the tropics. In: Bhat, R., Alias, A.K., Paliyath, G. (Eds.), Progress in Food Preservation. Wiley-Blackwell Publishers, London, pp. 581-601.

Ogendo, J.O., Deng, A.L., Kostyukovsky, M., Ravid, U., Matasyoh, J.C., Omolo, E.O., Kariuki, S.T., Kamau, A.W., Bett, P.K., Shaaya, E., 2013. Residual bioactivity of Ocimum americium L. and Tephrosia vogelii Hook essential oils against coleopteran pests and inhibition of wheat seed germination. In: Ogendo, J.O., Lukhoba, C.W., Bett Machocho, P.K.A.K. (Eds.), Proceedings of the First International Conference on Pesticidal Plants Volume 1 (August, 2013). ADAPPT-Network, Egerton University, pp. 91-94.
Papachristos, D.P., Stamopoulos, D.C., 2004. Fumigant toxicity of three essential oils on the eggs of Acanthoscelides obtectus (Say) (Coleoptera: Bruchidae). J. Stored Prod. Res. 40, 517.

Philips, T.W., Throne, J.E., 2010. Biorational approaches to managing stored product insects. Annu. Rev. Entomol. 55, 375-397.

Polatoğlu, K., Karakoç Ö, C., Gökçe, A., Gören, N., 2011. Insecticidal activity of Tanacetum chiliophyllum (Fisch. \& Mey.) var. monocephalum Grierson extracts and a new sesquiterpene lactone. Phytochem. Lett. 4, 432-435.

Rajendran, S., Muralidharan, N., 2005. Effectiveness of allyl acetate as a fumigant against five stored grain beetle pests. Pest Manage. Sci. 61, 97-101.

Rajendran, S., Sriranjini, V., 2008. Plant products as fumigants for stored-product insect control (review). J. Stored Prod. Res. 44, 126-135.

Rosman, V., Kalinovic, I., Korunic, Z., 2007. Toxicity of naturally occurring compounds of Lamiaceae and Lauraceae to three stored-product insects. J. Stored Prod. Res. 43, 349-355.

Ryan, M.F., Byrne, O., 1988. Plant insect coevolution and inhibition of acetylcholinesterase. J. Chem. Ecol. 14, 1965-1975.

SAS Institute, 2010. Using JMP 9. SAS Institute, Cary, NC.

Shaaya, E., Ravid, U., Paster, N., Juven, B.U., Zisman, U., Pissarev, V., 1991. Fumigant toxicity of essential oils against four major stored-product insects. J. Chem. Ecol. 17, 499-504.

Shaaya, E., Kostjukovsky, M., Eilberg, J., Sukprakarn, C., 1997. Plant oils as fumigants and contact insecticides for them control of stored-product insects. J. Stored Prod. Res. 33, 7-15.

Sokal, R.R., Rohlf, F.J., 1995. Biometry, 3rd ed. Freedman and Company, New York.

SPSS., 2010. SPSS Version 19, IBM Inc

Talukder, F.A., Howse, P.E., 1994. Repellent, toxic and food protectant effects of pithraj, Aphanamixis polystachya (Meliaceae) against the pulse beetle, Callosobruchus chinensis, in storage. J. Chem. Ecol. 20, 899-908.

Tapondjou, A.L., Adler, C., Fontem, D.A., Bouda, H., Reichmuth, C., 2005. Bioctivities of cymol and essential oils of Cupressus sempervirens and Euacalyptus saligna against Sitophilus zeamais Motschulsky and Tribolium confusum du Val. J. Stored Prod. Res. 41, 91-102.

Teke, G.N., Kemadjou, N.E., Kuiate, J.R., 2013. Chemical composition, antimicrobial properties and toxicity evaluation of the essential oil of Cupressus lusitanica Mill. leaves from Cameroon. BMC Complement. Altern. Med. 13, 130.

Toloza, A., Czygadlo, J., Cueto, G.M., Biurrun, F., Zerba, E., Picollo1, M., 2006. Fumigant and repellent properties of essential oils and component compounds against permethrin-resistant Pediculus humanus capitis (Anoplura: Pediculidae) from Argentina. J. Med. Entomol. 43, 889-895.

Tucker, A.M., Campbell, J.F., Arthur, F.H., Zhu, K.Y., 2014. Efficacy of Aerosol applications of methoprene and synergized pyrethrin against Tribolium castaneum adults and eggs. J. Econ. Entomol. 107, 1284-1291.

Van Den Dool, H., Kratz, P.D., 1963. A Generalization of the retention index system including linear temperature programmed gas-liquid partition chromatography. J. Chromatogr. 11, 463-471.

Wambua, L.M., Deng, A.L., Ogendo, J.O., Owuoche, J., Bett, P.K., 2011. Toxic, antifeedant and repellent activity of aqueous crude extracts of Tephrosia vogelii Hook on the larval stages of Helicoverpa armigera Hubner. Baraton Interdiscip. Res. J. 1, 19-29.

Wang, J., Zhu, F., Zhou, X.M., Niu, C.Y., Lei, C.L., 2006. Repellent and fumigant activity of essential oil from Artemisia vulgaris to Tribolium castaneum (Herbst) (Coleoptera: Tenebrionidae). J. Stored Prod. Res. 42, 339-347. 